\title{
Biodegradable esophageal stents for the treatment of refractory benign esophageal strictures
}

\author{
Paraskevas Gkolfakis ${ }^{a}$, Peter D. Siersema ${ }^{b}$, Georgios Tziatzios', Konstantinos Triantafyllouc, \\ loannis S. Papanikolaouc
}

Erasme University Hospital, Université Libre de Bruxelles, Brussels, Belgium; Radboud University Medical Center, Nijmegen, The Netherlands; "Attikon” University General Hospital, Medical School, National and Kapodistrian University of Athens, Greece

\begin{abstract}
This review attempts to present the available evidence regarding the use of biodegradable stents in refractory benign esophageal strictures, especially highlighting their impact on clinical success and complications. A comprehensive literature search was conducted in PubMed, using the terms "biodegradable" and "benign"; evidence from cohort and comparative studies, as well as data from one pooled analysis and one meta-analysis are presented. In summary, the results from these studies indicate that the effectiveness of biodegradable stents ranges from more than one third to a quarter of cases, fairly similar to other types of stents used for the same indication. However, their implementation may reduce the need for re-intervention during follow up. Biodegradable stents also seem to reduce the need for additional types of endoscopic therapeutic modalities, mostly balloon or bougie dilations. Results from pooled data are consistent, showing moderate efficacy along with a higher complication rate. Nonetheless, the validity of these results is questionable, given the heterogeneity of the studies included. Finally, adverse events may occur at a higher rate but are most often minor. The lack of high-quality studies with sufficient patient numbers mandates further studies, preferably randomized, to elucidate the exact role of biodegradable stents in the treatment of refractory benign esophageal strictures.
\end{abstract}

Keywords Biodegradable stent, benign esophageal stenosis

Ann Gastroenterol 2020; 33 (3): 1-8

\section{Introduction}

Some decades ago Celestin used an oval tube made of polyethylene carrying a soft barrel-shaped funnel to pass a

${ }^{\mathrm{a} D e p a r t m e n t ~ o f ~ G a s t r o e n t e r o l o g y, ~ H e p a t o p a n c r e a t o l o g y ~ a n d ~}$ Digestive Oncology, Erasme University Hospital, Université Libre de Bruxelles, Brussels, Belgium (Paraskevas Gkolfakis); ${ }^{b}$ Department of Gastroenterology and Hepatology, Radboud University Medical Center, Nijmegen, The Netherlands (Peter Siersema); 'Hepatogastroenterology Unit, $2^{\text {nd }}$ Department of Internal Medicine, "Attikon" University General Hospital, Medical School, National and Kapodistrian University of Athens, Greece (Georgios Tziatzios, Konstantinos Triantafyllou, Ioannis S. Papanikolaou)

\section{Conflict of Interest: None}

Correspondence to: Ioannis S. Papanikolaou, MD, PhD, Associate Professor, Hepatogastroenterology Unit, $2^{\text {nd }}$ Department of Internal Medicine and Research Unit, "Attikon" University General Hospital, Medical School, National and Kapodistrian University of Athens, Greece, Rimini 1, 12462, Athens, Greece, e-mail: ispapn@hotmail.com

Received 14 January 2020; accepted 15 February 2020; published online 13 April 2020

DOI: https://doi.org/10.20524/aog.2020.0482 malignant stenosis of the lower esophagus [1]. This rigid tube was one of the ancestors of today's esophageal stents. Technological progress has led to the development of more sophisticated stents with disease-specific technical characteristics. A new era in the treatment of esophageal diseases dawned with the development of self-expandable stents [2]. These stents, pre-loaded on an easyto-use delivery system, are released at the desired level of the esophagus under fluoroscopic control. Progressive self-expansion of the stent follows its deployment, allowing it to reach the final maximum diameter in 24-48 h. These stents are made from either metal or plastic and vary in terms of diameter and length, while their outer mesh can be either covered, uncovered or partially covered. While self-expandable stents (metallic or plastic) are effective for malignant indications [3], they are not globally accepted for the treatment of benign esophageal diseases, since they are associated with a significant risk of adverse events [4]. Uncovered or partially covered metal stents are prone to tissue overgrowth that may result in stent obstruction $[5,6]$. Additional interventions are then needed to treat the overgrowth tissue or to place another stent, aiming to restore stent patency $[7,8]$.

On the other hand, fully covered self-expandable metallic stents (FCSEMS) or self-expandable plastic stents (SEPS), despite being approved for the treatment of benign esophageal diseases, tend to migrate distally [9]. Stent migration will decrease the efficacy of 
the endoscopic treatment, while additional endoscopies, bearing a financial burden and potential morbidity, must be performed to remove the migrated stent $[10,11]$. In an effort to overcome the complications related to the use of metallic or plastic selfexpandable esophageal stents, the so-called biodegradable stents (BDS) were developed. The rationale behind BDS development is that a constant radial force can be applied for a specific amount of time (4-5 weeks), providing adequate time for the treatment of the underlying esophageal disease, while progressive hydrolysis-mediated self-degradation allows no development of tissue overgrowth [12]. Moreover, there is no need to perform an endoscopy to remove the stent, which normally is completely dissolved in 11-12 weeks [12]. The characteristics of BDS make them a very promising alternative for the treatment of benign esophageal diseases, particularly when the high complication risk of SEMS and SEPS is not acceptable.

Until now, 2 types of BDS have been used to treat benign esophageal diseases in humans. The first was originally manufactured in Japan (Marui Textile Machinery, Osaka, Japan) and was made from knitted poly-L-lactic acid monofilaments. After 2 initial reports, its further development and commercialization were stopped $[13,14]$. In contrast, the SX-ELLA BDS (ELLA-CS, Hradec Kralove, Czech Republic) has been applied in clinical practice and also remains available [15].

In this review we aim to present the currently available evidence regarding the use of the SX-ELLA BDS in refractory benign esophageal strictures, focusing on 2 main outcomes: clinical success and complications. To prepare this narrative review we conducted a PubMed comprehensive literature search, using the terms "biodegradable" and "benign".

\section{Refractory benign esophageal stricture (RBES)}

The main indication for BDS application is the treatment of RBES [16]. RBES are usually the result of a benign esophageal stricture (BES) - a decrease in the esophageal lumen diameter due to a cicatricial compromise or fibrosis-that does not respond to conventional treatment. Patients with RBES may present with dysphagia, while upper gastrointestinal (GI) endoscopy reveals no inflammatory signs or other mucosal abnormality $[17,18]$. RBES may be the result of gastroesophageal reflux disease (peptic stenosis), post-surgery (anastomotic stricture), post-radiotherapy, post-endoscopic intervention (mucosectomy or endoscopic submucosal dissection), or ingestion of caustic agents [19]. Moreover, it is often the complex BES, longer than $2 \mathrm{~cm}$, tortuous or with angulations, that are the most difficult to treat and often lead to RBES. In order to define RBES the criteria proposed by Kochman et al [20] are widely accepted (Table 1).

BES treatment should follow a step-up approach initiated by repeated esophageal bougie or balloon dilation (EBD) [16]. In case of persistence, EBD combined with triamcinolone injections in 4 quadrants at the level of the stenosis and electrocautery incision of the fibrotic tissue have been proposed, but neither approach has been proven superior to standard EBD [21,22].
Table 1 Kochman criteria to define a refractory benign esophageal stricture

1. Anatomic fibrotic esophageal restriction
2. Absence of inflammation or motility disorder
3. Inability to achieve a diameter $\geq 14 \mathrm{~mm}$ in 5 sessions of
dilatations at 2 -week intervals or inability to maintain a diameter
$\geq 14 \mathrm{~mm}$ for 4 weeks once $\geq 14$-mm diameter is achieved

RBES management is considered challenging, with only one third of patients achieving long-term symptom relief [23]. The rationale to place an esophageal stent in cases where all the aforementioned measures have failed is that placing a permanent dilator device at the level of the stricture could lead to its resolution by providing a constant radial force. Currently, the European Society of Gastrointestinal Endoscopy (ESGE), based on moderate-quality evidence, recommends the temporary placement of self-expandable stents (covered metal, plastic and BDS stents) for RBES [24]. Despite the fact that BDS have also occasionally been used for other indications $[25,26]$, treatment of RBES remains the only approved indication for BDS available in the market.

\section{The SX-ELLA BDS}

The SX-Ella stent (Fig. 1) is made of a semicrystalline, biodegradable polymer named polydioxanone. This material, which has also been used for absorbable surgical sutures, follows a hydrolysis-mediated dissolution further enhanced when the stent comes in contact with tissues or liquids with a low $\mathrm{pH}$ [12]. The degradation procedure is considered safe, and part of the dissolved material is absorbed by the GI tract, while another part is expelled. Based on in vitro studies this particular stent may maintain its initial radial force for 5 weeks, with a gradual reduction during the following weeks. In general, degradation of the stent is completed in 11-12 weeks (Fig. 2) [27]. It is available in different lengths $(60,80,100$ or $135 \mathrm{~mm})$ and stent body diameters $(18,20$, 23 or $25 \mathrm{~mm}$ ), while its maximum flare diameter ranges from 23$31 \mathrm{~mm}$. Before its deployment, it is loaded onto a delivery system ( $28 \mathrm{Fr}$ ) that is advanced over a guidewire into the esophagus. Then the stent can be released under fluoroscopic control, thanks to the radiopaque markers located at both its proximal and distal ends. Its uncovered body sheath allows the stent to be impacted against the esophageal wall, preventing distal migration. Once deployed, the delivery system is withdrawn and only minor stent repositioning is allowed. The only contraindications to its use are inability to pass the delivery system through the stricture, when the location of the stricture in the upper esophagus is too close to the cricopharyngeal muscle, and benign strictures secondary to previously performed laryngectomy [28].

\section{Data from cohort studies}

In the preliminary study by Repici et al [29], 21 patients with RBES were treated with BDS. Despite the large caliber 


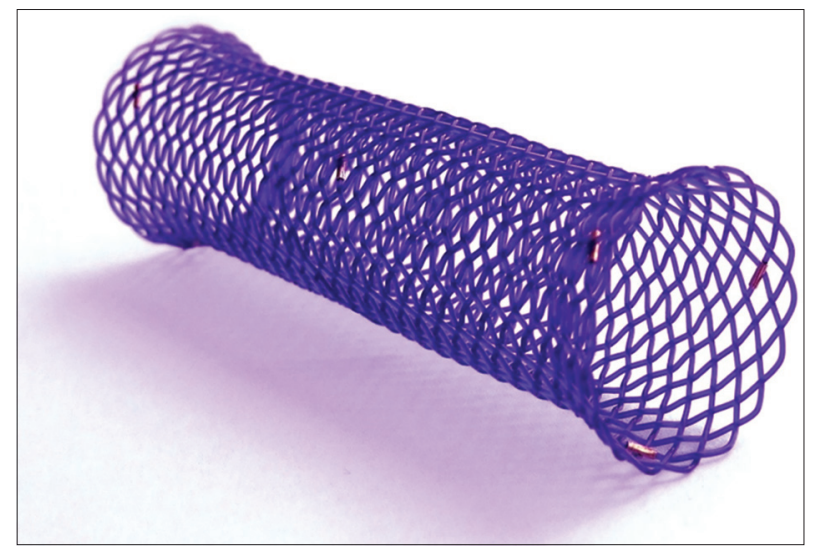

Figure 1 The SX-ELLA esophageal biodegradable stent (Photo courtesy of ELLA-CS s.r.o.)

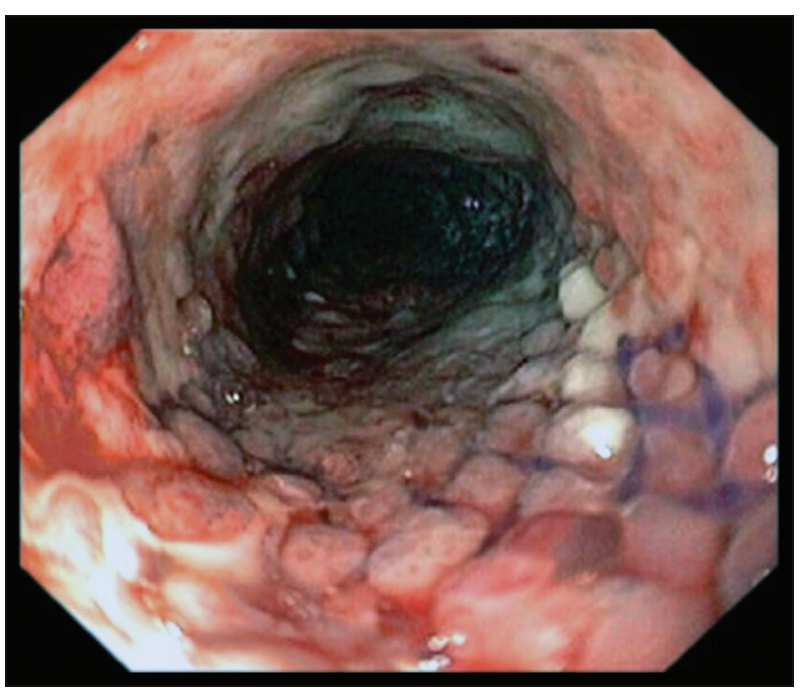

Figure 2 Endoscopic image showing partial SX-ELLA stent dissolution 4 weeks after its deployment with concurrent stenosis resolution

of the delivery system, BDS deployment was successful in all patients and almost half of the patients (45\%) were found to be dysphagia-free at the end of the long-term follow up. During follow-up endoscopies, the BDS remained in situ but were fragmented at month 3 in almost all patients and had completely dissolved in all cases by month 6 . Post-stent insertion chest pain and some minor bleeding were the only non-serious adverse events reported. Similar technical success rates were shown in the study published by Van Hooft et al [30].

In the study by Hirdes et al [31], 28 patients with RBES were treated with either single or sequential BDS placement. The overall clinical success rate, defined as being dysphagiafree at 6 months after stent placement, was 32\% (9/28). In total, $7 / 28$ (25\%) patients reached the primary endpoint after single stent placement, whereas 2 more patients reached the primary endpoint after placement of a second stent, leading the authors to conclude that BDS may offer a temporary effect on RBES that might increase after adding a second stent.

In a small series of 8 patients with RBES treated by BDS, there was a statistically significant difference in the interval between the endoscopic dilations necessary before stent placement, compared to the interval between stent placement and the first session of endoscopic dilation required after treatment with BDS: median: 34.3 days (interquartile range [IQR]: 23.1-48.3) vs. 149.5 days (IQR: 94.3-210), respectively; $\mathrm{P}=0.012[32]$.

On the other hand, the outcomes of BDS placement in the treatment of caustic stenosis were not as encouraging. In a case series that included 13 patients, only 23\% (3/13) remained dysphagia-free at 6 months after BDS placement, whereas at 12-month follow up, the success rate dropped to merely one single patient who remained free of symptoms [33].

Finally, a recent cohort study from Japan [34], assessed the efficacy and safety of BDS in cases of RBES following curative treatment of esophageal cancer (including radical esophagectomy, endoscopic submucosal dissection or chemoradiotherapy). Among 18 patients, 12 (66.7\%) had a significant improvement in dysphagia score $(<2)$ at 12 weeks of follow up, but only $3 / 18$ (16.7\%) maintained this beneficial effect at 6 months of follow up.

\section{Data from comparative studies}

Once the feasibility of BDS therapy was established, researchers tried to compare its efficacy to the other available modalities of RBES treatment: namely, other stents and endoscopic balloon/bougie dilation. Table 2 depicts the available comparative studies as well as their main outcomes. In all studies the SX-Ella BD stent (Ella-CS, Hradec Králové, Czech Republic) was used.

SX-Ella BDS was evaluated in comparison to different self-expandable stents (SEPS or FCSEMS) in 2 studies. Van Boeckerl et al [35] compared 38 consecutive patients with RBES treated either by BDS $(n=18)$ or SEPS for 6 weeks $(n=20$; Polyflex, Boston Scientific, Natick, MA). All stents were deployed under fluoroscopic control and correct positioning was confirmed endoscopically and/or radiologically. Clinical success, defined as lack of dysphagia at the end of the 6-month follow up did not differ between the 2 groups: $6 / 18$ (33\%) vs. $6 / 16(30 \%)$ in the BDS and SEPS groups, respectively $(\mathrm{P}=0.83)$. However, patients in the BDS group required significantly fewer re-interventions during the follow up per stent placed ( 0.8 vs. $1.3 ; \mathrm{P}=0.03$ ). Major complications and migration rates did not differ between the 2 groups and no stent-related deaths occurred.

In the second study, Canena et al [36] compared different stents (BDS, SEPS and FCSEMS) for the treatment of RBES. Ten patients were recruited in each arm, while SEPS and FCSEMS were left in place for 12 weeks. The primary endpoint (defined as "clinical success") was dysphagia resolution after the end of long-term ( 8 months) follow up. The 3 groups did not differ in terms of clinical success $(\mathrm{P}=0.27)$ since $10 \%, 30 \%$ and $40 \%$ of the patients were dysphagia-free at the end of the follow up in the SEPS, BDS and FCSEMS groups, respectively. Regression analysis showed that BDS and FCSEMS were related to a significantly lower risk of re- 
Table 2 Comparative studies evaluating BDS efficacy in patients with RBES

\begin{tabular}{|c|c|c|c|c|c|c|c|c|c|}
\hline Reference & Study design & Comparator & $\begin{array}{l}\text { Participants } \\
\text { (n) }\end{array}$ & $\begin{array}{r}\text { Clinical suc } \\
(\%)\end{array}$ & ess rate & $\begin{array}{r}\text { Complicat } \\
(\%\end{array}$ & in rate & $\begin{array}{r}\text { Migratio } \\
(\%)\end{array}$ & rate \\
\hline $\begin{array}{l}\text { Van Boeckel } \\
\text { et al [35] }\end{array}$ & $\begin{array}{l}\text { Retrospective } \\
\text { Single-center }\end{array}$ & SEPS (6 weeks) & $\begin{array}{l}\text { BDS: } 18 \\
\text { SEPS: } 20\end{array}$ & $\begin{array}{l}\text { BDS: } 33 \\
\text { SEPS: } 30\end{array}$ & $\mathrm{P}=0.83$ & $\begin{array}{l}\text { BDS: } 38.8 \\
\text { SEPS: } 15\end{array}$ & $\mathrm{P}=0.09$ & $\begin{array}{l}\text { BDS: } 22.2 \\
\text { SEPS: } 25\end{array}$ & $\mathrm{P}=0.85$ \\
\hline $\begin{array}{l}\text { Canena et al } \\
\text { [36] }\end{array}$ & $\begin{array}{l}\text { Prospective, } \\
\text { observational } \\
\text { Multi-centric }\end{array}$ & $\begin{array}{l}\text { SEPS ( } 12 \text { weeks) } \\
\text { FCSEMS ( } 12 \\
\text { weeks) }\end{array}$ & $\begin{array}{l}\text { BDS: } 10 \\
\text { SEPS: } 10 \\
\text { FCSEMS: } 10\end{array}$ & $\begin{array}{l}\text { BDS: } 30 \\
\text { SEPS: } 10 \\
\text { FCSEMS: } 40\end{array}$ & $\mathrm{P}=0.27$ & $\begin{array}{l}\text { BDS: } 50 \\
\text { SEPS: } 70 \\
\text { FCSEMS: } 60\end{array}$ & $\mathrm{P}=0.38$ & $\begin{array}{l}\text { BDS: } 20 \\
\text { SEPS: } 60 \\
\text { FCSEMS: } 30\end{array}$ & $\mathrm{P}=0.16$ \\
\hline $\begin{array}{l}\text { Dhar et al } \\
\text { [37] }\end{array}$ & $\begin{array}{l}\text { Pilot RCT } \\
\text { Multi-center }\end{array}$ & Balloon dilation & $\begin{array}{l}\text { BDS: } 10 \\
\text { Balloon dilation: } 7\end{array}$ & $\begin{array}{l}{ }^{*} 1.17(0.9) \\
\text { vs. } 0(0)\end{array}$ & $\mathrm{P}=0.004$ & $\begin{array}{l}{ }^{* *} \text { BDS: } 4.9 \\
\text { Balloon } \\
\text { dilation: } 1\end{array}$ & $\mathrm{P}=0.01$ & NA & \\
\hline $\begin{array}{l}\text { Walter et al } \\
\text { [38] }\end{array}$ & $\begin{array}{l}\text { RCT } \\
\text { Multi-center }\end{array}$ & $\begin{array}{l}\text { Endoscopic } \\
\text { dilation }\end{array}$ & $\begin{array}{l}\text { BDS: } 32 \\
\text { ED: } 34\end{array}$ & ${ }^{* * *} 0$ vs. 1 & $\mathrm{P}<0.001$ & $\begin{array}{l}{ }^{* *} \text { BDS: } 4.1 \\
\text { ED: } 4.2\end{array}$ & $\mathrm{P}=0.42$ & $\begin{array}{l}\text { BDS: } 0.03 \\
\text { ED: } 0\end{array}$ & $\mathrm{P}=\mathrm{ns}$ \\
\hline
\end{tabular}

*: mean (standard deviation) dysphagia score at 3 and 6 months of follow up

${ }^{* *}$ : median number of complications per patient

${ }^{* * *}$ : median number of therapeutic endoscopic dilation for recurrent stricture at 3 months of follow up

BDS, biodegradable stent; RBES, refractory benign esophageal stricture; SEPS, self-expandable plastic stent; FCSEMS, fully-covered self-expandable metallic stent;

$R C T$, randomized controlled trial; NA, non-applicable; ED, endoscopic dilation; ns, non-significant

intervention during the follow up and that stricture length was an independent risk factor for higher recurrence rates (hazard ratio $1.37,95 \%$ confidence interval 1.08-1.75; $\mathrm{P}=0.011)$. Two major complications occurred in the BDS group (1 bleeding necessitating transfusion and 1 severe chest pain requiring morphine), but overall complications did not differ among the 3 groups. Groups also did not differ regarding migration rate. All BDS were completely dissolved at 6 months after deployment.

Two randomized controlled trials (RCTs) attempted to elucidate differences between BDS and consecutive endoscopic dilations for the management of RBES [37,38]. In a pilot multicenter UK study [37], investigators randomized 17 patients between BDS $(n=10)$ or balloon dilation $(n=7)$. Balloon dilation was considered successful when a luminal diameter $>15 \mathrm{~mm}$ was achieved, even if periodical dilation sessions (every 2 weeks) were required. The primary endpoint was the average dysphagia score at 6 months of follow up. Patients in the BDS groups had a better (lower) dysphagia score compared to patients treated with endoscopic dilationsmean difference 1.17 (95\%CI 0.63-1.78); $\mathrm{P}=0.03$-but this difference was no longer statistically significant when patients were followed for another 6 months (12 months follow up was one of the secondary endpoint of the study): mean difference 1.06 (0.43-1.81); $\mathrm{P}=0.07$. Moreover, the $\mathrm{BDS}$ group was associated with a higher rate of complications. However, these results should be appraised critically: the initial study design required the recruitment of 50 patients, but the extremely low recruitment rate led to interruption after only 17 had been enrolled. For this reason, the primary endpoint was shifted post hoc from 12 months of follow up to 6 months, to achieve more completed dysphagia scores available for final analysis.

In the most recent RCT [38], patients with dysphagia (score $\geq 2$ on the Ogilvie scale and $\leq 21$ on the Dakkak and Bennett scale) and previous endoscopic dilation $>16 \mathrm{~mm}$ within the previous 12 months were randomized to receive either BDS or endoscopic dilation. Both balloon and bougie treatment were allowed, with a period of 2 weeks to reach the desired lumen diameter. In this study, the primary endpoint was the number of repeated endoscopic dilations for recurrent strictures within 3 and 6 months from the intervention time. Overall, 66 patients were randomized (BDS, $n=32$ vs. endoscopic dilation, $n=34$ ). The study concluded that BDS was associated with a temporary reduction in the number of repeat dilation sessions compared to patients in the standard endoscopic dilation arm. During the first 3 months of follow up, patients in the BDS group underwent significantly fewer endoscopic dilations due to recurrent esophageal strictures compared to patients of the standard endoscopic dilation group (median 0 vs. $1 ; \mathrm{P}<0.0001$ ); however, this statistically significant difference was no longer present at 6 months of follow up ( 1 vs. $1 ; \mathrm{P}=0.31$ ). Interestingly, patients in the BDS group needed fewer repeat endoscopic dilation sessions to treat recurrent strictures at 3, 6 and 12 months, compared to those in the standard endoscopic treatment arm.

From the aforementioned studies it can be concluded that all types of self-expandable stents offer moderate ( 30-40\%) long-term dysphagia relief. However, at least when compared to SEPS, BDS offer the advantage of requiring significantly fewer re-interventions during follow up. Similarly, in patients with RBES, BDS placement could provide a significant temporary benefit compared to classic endoscopic dilation, at least for the first 3 months after stent placement. Therefore, this could lead to fewer endoscopic dilations, performed at a later stage, providing patients with an improved treatment experience, combined with reducing costs for the healthcare system.

\section{Pooled data}

Data from RCTs comparing different stent types (including BDS) for RBES treatment are presented in 2 studies $[39,40]$ : one pooled analysis and one meta-analysis (Table 3 ). In the study by van Halsema [39], data from 8 prospective studies were pooled. Based on the included studies, clinical success 
Table 3 Pooled analysis and meta-analysis evaluating different stent types for RBES

\begin{tabular}{|c|c|c|c|c|c|c|c|}
\hline Reference & $\begin{array}{l}\text { Study } \\
\text { design }\end{array}$ & $\begin{array}{l}\text { Studies } \\
\text { (n) }\end{array}$ & $\begin{array}{l}\text { Patients } \\
\text { (n) }\end{array}$ & $\begin{array}{l}\text { Type of } \\
\text { studies }\end{array}$ & $\begin{array}{c}\text { Clinical success rate } \\
(\%)\end{array}$ & Migration rate (\%) & $\begin{array}{c}\text { Complication rate } \\
(\%)\end{array}$ \\
\hline $\begin{array}{l}\text { Van Halsema } \\
\text { et al [39] }\end{array}$ & $\begin{array}{l}\text { Pooled } \\
\text { analysis }\end{array}$ & 8 & 232 & 8 prospective & $\begin{array}{c}\text { Overall: } 24.2 \\
\text { SEPS: } 27.1 \\
\text { SEMS: } 14.1 \\
\text { BDS: } 32.9\end{array}$ & $\begin{array}{l}\text { Overall: } 24.6 \\
\text { SEPS: } 27.1 \\
\text { SEMS: } 31.8 \\
\text { BDS: } 14.3\end{array}$ & $\begin{array}{l}\text { Overall: } 31 \\
\text { SEPS: } 25.7 \\
\text { SEMS: } 28.2 \\
\text { BDS: } 38.9\end{array}$ \\
\hline $\begin{array}{l}\text { Fuccio et al } \\
{[40]}\end{array}$ & $\begin{array}{l}\text { Meta- } \\
\text { analysis }\end{array}$ & 18 & 444 & $\begin{array}{l}10 \text { prospective } \\
8 \text { retrospective }\end{array}$ & $\begin{array}{c}\text { Overall: } 40.5 \\
\text { (95\%CI } 31.5-49.5) \\
\text { SEPS: } 46.2 \\
\text { (95\%CI } 27-66.3] \\
\text { SEMS: } 40.1 \\
\text { (95\%CI } 28.1-54.1] \\
\text { BDS: } 32.9 \\
(95 \% \text { CI } 23.1-44.1)\end{array}$ & $\begin{array}{c}\text { Overall: } 28.6 \\
(95 \% \text { CI } 21.9-37.1) \\
\text { SEPS: } 33.3 \\
(95 \% \text { CI } 19.4-51.5] \\
\text { SEMS: } 31.5 \\
(95 \% \text { CI } 22.5-42.2) \\
\text { BDS: } 15.3 \\
(95 \% \text { CI } 8.3-25.4)\end{array}$ & $\begin{array}{c}\text { Overall: } 20.6 \\
\text { (95\%CI 15.3-28.1) } \\
\text { SEPS: } 19.4 \\
(95 \% \text { CI } 12.3-30.1) \\
\text { SEMS: } 21.9 \\
(95 \% \text { CI } 11.5-37.5) \\
\text { BDS: } 21.9 \\
(95 \% \text { CI } 13.8-32.9)\end{array}$ \\
\hline
\end{tabular}

RBES, refractory benign esophageal stricture; SEPS, self-expandable plastic stent; FCSEMS, fully covered self-expandable metallic stent; BDS, biodegradable stent; CI, confidence interval

rate was defined as the absence of dysphagia at the end of the predefined follow-up period; in all studies the Kochman criteria were used to define RBES. Overall, 232 patients were treated with either BDS $(n=77)$, FCSEMS $(n=85)$ or SEPS $(\mathrm{n}=70)$. The overall clinical success for stent placement was $24.2 \%$, but the highest rate of clinical success was achieved when BDS were used $(32.9 \%)$, compared with FCSEMS and SEPS (14.1\% and $27.1 \%$, respectively). Migration rate was $24.6 \%$ with no important variation among different stents. Finally, the complication rate was $31 \%$, with $17.7 \%$ consisting of major complications. Interestingly, BDS were associated with more major complications (28.6\%) compared to FCSEMS and SEPS (10.6\% and $14.3 \%$, respectively). Despite the overall non-encouraging results, this pooled analysis indicated a higher clinical success rate for BDS compared to FCSEMS and SEMS, setting them as a relatively more efficient modality for RBES treatment. However, this needs to be balanced against a higher rate of complications.

In a meta-analysis of 10 prospective and 8 retrospective studies (444 patients) [40], the long-term efficacy of single stenting (BDS, FCSEMS or SEPS) for RBES was evaluated. According to the study protocol, patients should have undergone at least 2 endoscopic dilations before being treated with stent therapy and had to be followed up for at least 4 weeks; however, RBES was not defined by a global definition. Overall clinical success-no dysphagia at the end of follow up-was $40.5 \%$ (random effect model; 95\%CI 31.5-49.5). Subgroup analysis did not reveal any statistical differences between the 3 groups: $32.9 \%(23.1-44.1)$ vs. $40.1 \%(28.1-54.1)$ vs. $46.2 \%(27-66.3)$ for BDS, FCSEMS and SEPS, respectively. Meta-regression analysis identified stricture etiology as a potential factor explaining the significant heterogeneity detected $\left(I^{2}=65 \%\right)$, with strictures following esophagectomy or radiotherapy being more often treated with stent implantation. The pooled migration rate was $28.6 \%$ (21.9-37.1) but, despite the fact that BDS was associated with a lower migration rate (15.3\%), this was not statistically different between the 3 groups. Finally, the overall complication rate was $20.6 \%$ (15.3-28.1), again with no differences noticed among the 3 groups.

\section{Safety outcomes - complications}

BDS deployment is considered an interventional procedure and, as such, has been associated with various adverse events. Table 4 depicts both serious and non-serious adverse events, as reported in studies of different designs in which the SX-ELLA BDS was evaluated.

Among the non-serious adverse events, post-stenting chest pain is the one most commonly reported [31,34]. It starts following stent deployment and reaches its highest intensity during the first couple of days post-release. Retrosternal chest pain reflects the process of stent deployment in order to achieve its planned diameter. The pain is usually self-limited; however, analgesics, including opioids, may be required to control it [41]. Rarely, the pain may persist for a long period of time or may be not tolerated by the patient, leading to early stent removal to relieve the patient's symptoms. Apart from pain, a variety of miscellaneous specific or non-specific GI symptoms may also occur, including reflux, and nausea and vomiting [34,42]. They typically appear once the stent has been inserted and are easily managed symptomatically, while sometimes medication may be required.

In addition, dysphagia recurrence has been described as a consequence of BDS treatment [38]. While late dysphagia occurrence is frequently related to treatment failure and recurrence of the RBES, early dysphagia might be the result of BDS collapse, or more frequently tissue in-/overgrowth $[43,44]$. This hyperplastic tissue may significantly obstruct the esophageal lumen, leading to dysphagia. For BDS-associated hyperplasia different techniques have been reported. Among them, coagulation using argon plasma, endoscopic balloon dilations and placement of a sequential stent have been applied with variable results [43-46].

In the reviewed literature, no deaths of RBES patients treated with BDS were identified. Mortality could mostly be attributed to concurrent comorbidities and other extra-esophageal disease. However, various serious adverse events have been reported. Among these, the main GI-related severe adverse events include severe chest or abdominal pain, GI bleeding, 
Table 4 Safety outcomes expressed as number of adverse events in studies assessing SX-ELLA BDS for RBES*

\begin{tabular}{|c|c|c|c|}
\hline Reference & Type of study & $\begin{array}{l}\text { AE }(\mathrm{n}) \text { in } \mathrm{BDS} \\
\text { arm Overall } \\
(S A E / n S A E)\end{array}$ & Comment on AEs \\
\hline $\begin{array}{l}\text { Walter et al } \\
{[38]}\end{array}$ & RCT & $\begin{array}{c}131 \\
23 / 108\end{array}$ & $\begin{array}{l}\text { SAE: clinical GI symptoms }(n=5) \text {, migration }(n=1) \text {, dysphagia }(n=3) \text {, peritonitis }(n=1) \text {, liver } \\
\text { abscess }(n=1) \text {, new symptoms requiring hospitalization }(n=1) \text {, tracheoesophageal fistula }(n=2) \text {, } \\
\text { pneumonia }(n=1) \text {, respiratory insufficiency }(n=1) \text {, cardiovascular }(n=1) \text {, neurologic }(n=1) \text {, } \\
\text { vascular }(n=1) \text {, access site }(n=1) \text {, oncology }(n=3) \text {, miscellaneous non-GI events }(n=1) \\
\text { nSAE: clinical GI symptoms }(n=6) \text {, dysphagia }(n=71) \text {, occlusion }(n=5) \text {, miscellaneous GI } \\
\text { events }(n=17) \text {, miscellaneous pulmonary events }(n=3) \text {, orthopedic }(n=2) \text {, urologic }(n=1) \text {, } \\
\text { miscellaneous non-GI events }(n=3)\end{array}$ \\
\hline $\begin{array}{l}\text { Yano et al } \\
{[34]}\end{array}$ & $\begin{array}{l}\text { Prospective } \\
\text { cohort study }\end{array}$ & $\begin{array}{c}29 \\
4 / 25\end{array}$ & $\begin{array}{l}\text { SAE: esophageal stricture }(n=1) \text {, esophago-bronchial fistula }(n=1) \text {, bone infection }(n=1) \text {, soft } \\
\text { tissue infection }(n=1) \\
\text { nSAE: post-stenting chest pain }(n=9) \text {, reflux }(n=5) \text {, fever }(n=2) \text {, vomiting }(n=3) \text {, dysphagia } \\
(n=1) \text {, cough }(n=1) \text {, malaise }(n=1) \text {, neck pain }(n=1) \text {, abdominal pain }(n=1) \text {, sore throat }(n=1)\end{array}$ \\
\hline $\begin{array}{l}\text { Nogales } \\
\text { et al }[44]\end{array}$ & $\begin{array}{l}\text { Retrospective } \\
\text { comparative }\end{array}$ & $\begin{array}{c}4 \\
0 / 4\end{array}$ & $\begin{array}{l}\text { SAE: NA } \\
\text { nSAE: BDS collapse during absorption }(n=1) \text {, tissue in/overgrowth }(n=3)\end{array}$ \\
\hline $\begin{array}{l}\text { Kochhar } \\
\text { et al [33] }\end{array}$ & $\begin{array}{l}\text { Retrospective } \\
\text { cohort study }\end{array}$ & $\begin{array}{c}19 \\
0 / 19\end{array}$ & $\begin{array}{l}\text { SAE: NA } \\
\text { nSAE: post-stenting chest pain }(n=13) \text {, tissue in/overgrowth }(n=6)\end{array}$ \\
\hline $\begin{array}{l}\text { Sigounas } \\
\text { et al [32] }\end{array}$ & $\begin{array}{l}\text { Retrospective } \\
\text { cohort study }\end{array}$ & $\begin{array}{c}4 \\
1 / 3\end{array}$ & $\begin{array}{l}\text { SAE: sepsis post-stent insertion successfully treated }(n=1) \\
\text { nSAE: post-stenting chest pain }(n=1) \text {, food bolus obstruction }(n=2)\end{array}$ \\
\hline $\begin{array}{l}\text { McCain } \\
\text { et al [42] }\end{array}$ & Cohort study & $\begin{array}{c}1 \\
0 / 1\end{array}$ & $\begin{array}{l}\text { SAE: NA } \\
\text { nSAE: post-stenting chest pain }(\mathrm{n}=1)\end{array}$ \\
\hline $\begin{array}{l}\text { Dhar et al } \\
{[37]}\end{array}$ & RCT & $\begin{array}{c}12 \\
2 / 10\end{array}$ & $\begin{array}{l}\text { SAE: abdominal pain }(n=1) \text {, dysphagia }(n=1) \\
\text { nSAE: acute pancreatitis }(n=1) \text {, cough }(n=1) \text {, diverticulosis }(n=1) \text {, dry mouth }(n=1) \text {, bleeding } \\
(n=1) \text {, hyperglycemia }(n=1) \text {, insomnia }(n=1) \text {, esophageal candidiasis }(n=1) \text {, pain }(n=1) \text {, } \\
\text { positive fecal occult blood test }(n=1)\end{array}$ \\
\hline $\begin{array}{l}\text { Karakan } \\
\text { et al }[41]\end{array}$ & Case series & $\begin{array}{c}11 \\
1 / 10\end{array}$ & $\begin{array}{l}\text { SAE: severe headache }(n=1) \\
\text { nSAE: chest pain }(n=4) \text { treated by analgesics, nausea }(n=3) \text {, tissue in=overgrowth }(n=3)\end{array}$ \\
\hline $\begin{array}{l}\text { Hirdes et al } \\
{[31]}\end{array}$ & Cohort study & $\begin{array}{c}15 \\
11 / 4\end{array}$ & $\begin{array}{l}\text { SAE: chest pain }(n=6) \text {, bleeding }(n=3) \text {, fever }(n=1) \text {, aspiration pneumonia }(n=1) \\
\text { nSAE: chest pain }(n=2) \text {, reflux }(n=1) \text {, vomiting }(n=1)\end{array}$ \\
\hline $\begin{array}{l}\text { Canena } \\
\text { et al }[36]\end{array}$ & $\begin{array}{l}\text { Prospective } \\
\text { cohort study }\end{array}$ & $\begin{array}{c}7 \\
2 / 5\end{array}$ & $\begin{array}{l}\text { SAE: bleeding }(n=1) \text {, severe post-stenting chest pain }(n=1) \\
\text { nSAE: tissue in/overgrowth }(n=3) \text {, stent migration }(n=2)\end{array}$ \\
\hline $\begin{array}{l}\text { Van Hooft } \\
\text { et al [30] }\end{array}$ & $\begin{array}{l}\text { Prospective } \\
\text { cohort study }\end{array}$ & $\begin{array}{c}4 \\
0 / 4\end{array}$ & $\begin{array}{l}\text { SAE: NA } \\
\text { nSAE: stent re-obstruction }(n=4) ; 2 \text { of them due to tissue in growth }\end{array}$ \\
\hline $\begin{array}{l}\text { Van } \\
\text { Boeckel } \\
\text { et al }[35]\end{array}$ & $\begin{array}{l}\text { Observational } \\
\text { comparative }\end{array}$ & $\begin{array}{c}7 \\
4 / 3\end{array}$ & $\begin{array}{l}\text { SAE: bleeding }(n=2) \text { needing transfusion but no further intervention, chest pain }(n=2) \\
\text { nSAE: reflux }(n=1) \text {, nausea }(n=1) \text {, vomiting }(n=1)\end{array}$ \\
\hline $\begin{array}{l}\text { Repici et al } \\
{[29]}\end{array}$ & $\begin{array}{l}\text { Prospective } \\
\text { cohort study }\end{array}$ & $\begin{array}{c}4 \\
0 / 4\end{array}$ & $\begin{array}{l}\text { SAE: NA } \\
\text { nSAE: post-stenting chest pain }(n=3) \text { treated by analgesics, minor bleeding }(n=1) \text { with no } \\
\text { significant hemoglobin drop }\end{array}$ \\
\hline
\end{tabular}

*: according to each study's definitions

$A E$, adverse events; GI, gastrointestinal; SAE, serious adverse events; $n S A E$, non-serious adverse events; RCT, randomized controlled trial; BDS, biodegradable stent; NA, non-applicable

peritonitis and recurrence of dysphagia necessitating further or new hospitalizations [38]. Adverse events originating from the respiratory system have also been described, such as de novo formation of an esophago-bronchial fistula, or respiratory pneumonia following stent release [47]. Finally, a few septic episodes have been reported, including a case of soft tissue infection [32,34].

Regarding cases of GI bleeding, this could be explained, at least partially, by an interaction between the degrading parts of the stent and the tissue that grows as a reaction to the chemical procedure taking place during BDS degradation. It should be noted that most cases concern minor bleeding and only a few cases required a further intervention, such as transfusion or endoscopic hemostasis.

As already discussed in the previous section, a recent metaanalysis did not reveal any difference in complication rates between patients treated with BDS and those treated with SEMS or SEPS [40]. Moreover, Imaz-Iglesia et al [48] analyzed data from 5 studies ( 3 comparative and 2 cohort studies) including a total of 132 patients with REBS undergoing different treatments (86 BDS, 30 SEPS, 10 FCSEMS, and 6 endoscopic balloon dilation). The overall complication rate in these studies ranged 
from $33.3-50 \%$. Severe dysphagia and severe post-stenting chest pain were the most commonly reported severe adverse events, whereas moderate pain, moderate dysphagia and tissue hyperplasia were the most commonly reported minor adverse events. However, the volume of cases presented in the current literature allows one to claim that BDS deployment should be considered as a safe therapeutic procedure, with the prerequisite that all necessary precautionary measures (including accurate indication, fluoroscopy-guided deployment, etc.) are applied.

\section{Concluding remarks}

The current literature illustrates that BDS are a useful tool in the therapeutic armamentarium for the treatment of RBES. However, their superiority compared to other available therapeutic options remains to be demonstrated with clearcut impressive outcomes. On the other hand, although complications associated to BDS are usually minor, severe complications also occur at relatively high rates. As highquality data are still relatively sparse, the exact role of BDS in the treatment of RBES remains under evaluation and thus more evidence, especially from RCTs, will be welcome in order to elucidate the proper clinical settings for their use.

\section{References}

1. Celestin LR. Permanent intubation in inoperable cancer of the oesophagus and cardia: a new tube. Ann R Coll Surg Engl 1959;25:165-170.

2. Vleggaar FP, Siersema PD. Expandable stents for malignant esophageal disease. Gastrointest Endosc Clin N Am 2011;21:377388, vii.

3. Hindy P, Hong J, Lam-Tsai Y, Gress F. A comprehensive review of esophageal stents. Gastroenterol Hepatol (N Y) 2012;8:526-534.

4. Dua KS. Expandable stents for benign esophageal disease. Gastrointest Endosc Clin N Am 2011;21:359-376, vii.

5. Vermeulen BD, Siersema PD. Esophageal stenting in clinical practice: an overview. Curr Treat Options Gastroenterol 2018; 16:260-273.

6. Gangloff A, Lecleire S, Di Fiore A, et al. Fully versus partially covered self-expandable metal stents in benign esophageal strictures. Dis Esophagus 2015;28:678-683.

7. Verschuur EM, Repici A, Kuipers EJ, Steyerberg EW, Siersema PD. New design esophageal stents for the palliation of dysphagia from esophageal or gastric cardia cancer: a randomized trial. Am J Gastroenterol 2008;103:304-312.

8. Reijm A, Didden P, Schelling S, Siersema P, Bruno M, Spaander M. Twenty-three years of self-expandable metal stents placement for malignant esophageal strictures. Endoscopy 2018;50:S31.

9. Uitdehaag MJ, van Hooft JE, Verschuur EM, et al. A fully-covered stent (Alimaxx-E) for the palliation of malignant dysphagia: a prospective follow-up study. Gastrointest Endosc 2009;70:10821089.

10. Harries R, Campbell J, Ghosh S. Fractured migrated oesophageal stent fragment presenting as small bowel obstruction three years after insertion. Ann R Coll Surg Engl 2010;92:W14-W15.

11. Reddy VM, Sutton CD, Miller AS. Terminal ileum perforation as a consequence of a migrated and fractured oesophageal stent. Case Rep Gastroenterol 2009;3:61-66.

12. Rejchrt S, Kopáčová M, Bártová J, Vacek Z, Bureš J. Intestinal biodegradable stents. Initial experience in the Czech Republic. Folia Gastroenterol Hepatol 2009;7:7-11

13. Tanaka T, Takahashi M, Nitta N, et al. Newly developed biodegradable stents for benign gastrointestinal tract stenoses: a preliminary clinical trial. Digestion 2006;74:199-205.

14. Saito Y, Tanaka T, Andoh A, et al. Usefulness of biodegradable stents constructed of poly-l-lactic acid monofilaments in patients with benign esophageal stenosis. World J Gastroenterol 2007; 13:3977-3980.

15. van Boeckel PG, Vleggaar FP, Siersema PD. Biodegradable stent placement in the esophagus. Expert Rev Med Devices 2013;10:37-43.

16. Hirdes MM, Vleggaar FP, Siersema PD. Stent placement for esophageal strictures: an update. Expert Rev Med Devices 2011;8:733-755.

17. Patterson DJ, Graham DY, Smith JL, et al. Natural history of benign esophageal stricture treated by dilatation. Gastroenterology 1983;85:346-350.

18. Sandha GS, Marcon NE. Expandable metal stents for benign esophageal obstruction. Gastrointest Endosc Clin N Am 1999;9:437-446.

19. Siersema PD. Treatment options for esophageal strictures. Nat Clin Pract Gastroenterol Hepatol 2008;5:142-152.

20. Kochman ML, McClave SA, Boyce HW. The refractory and the recurrent esophageal stricture: a definition. Gastrointest Endosc 2005;62:474-475.

21. Ramage JI Jr, Rumalla A, Baron $\mathrm{TH}$, et al. A prospective, randomized, double-blind, placebo-controlled trial of endoscopic steroid injection therapy for recalcitrant esophageal peptic strictures. Am J Gastroenterol 2005;100:2419-2425.

22. Hordijk ML, van Hooft JE, Hansen BE, Fockens P, Kuipers EJ. A randomized comparison of electrocautery incision with Savary bougienage for relief of anastomotic gastroesophageal strictures. Gastrointest Endosc 2009;70:849-855.

23. Repici A, Small AJ, Mendelson A, et al. Natural history and management of refractory benign esophageal strictures. Gastrointest Endosc 2016;84:222-228.

24. Spaander MC, Baron TH, Siersema PD, et al. Esophageal stenting for benign and malignant disease: European Society of Gastrointestinal Endoscopy (ESGE) Clinical Guideline. Endoscopy 2016;48:939-948.

25. Gornals JB, Rivas L, Aranda H, Miro M, Galan M. Customized partially covered biodegradable stent for anastomotic leakage after esophagojejunostomy. Endoscopy $2015 ; 47$ Suppl 1 UCTN:E137-E138.

26. Yang K, Ling C, Yuan T, Zhu Y, Cheng Y, Cui W. Polymeric biodegradable stent insertion in the esophagus. Polymers (Basel) $2016 ; 8$.

27. Stivaros SM, Williams LR, Senger C, Wilbraham L, Laasch HU. Woven polydioxanone biodegradable stents: a new treatment option for benign and malignant oesophageal strictures. Eur Radiol 2010;20:1069-1072.

28. [No author] SX-ELLA stent esophageal degradable BD - BD STENT. Available at: https://www.ellacs.eu/sx-ella-stent-jicnovybiodegradabilni-bd-stent.html [Accessed 2 April 2020].

29. Repici A, Vleggaar FP, Hassan C, et al. Efficacy and safety of biodegradable stents for refractory benign esophageal strictures: the BEST (Biodegradable Esophageal Stent) study. Gastrointest Endosc 2010;72:927-934.

30. van Hooft JE, van Berge Henegouwen MI, Rauws EA, Bergman JJ, Busch OR, Fockens P. Endoscopic treatment of benign anastomotic esophagogastric strictures with a biodegradable stent. Gastrointest Endosc 2011;73:1043-1047.

31. Hirdes MM, Siersema PD, van Boeckel PG, Vleggaar FP. Single and 
sequential biodegradable stent placement for refractory benign esophageal strictures: a prospective follow-up study. Endoscopy 2012;44:649-654.

32. Sigounas DE, Siddhi S, Plevris JN. Biodegradable esophageal stents in benign and malignant strictures - a single center experience. Endosc Int Open 2016;4:E618-E623.

33. Kochhar R, Samanta J, Basha J, et al. Biodegradable stents for caustic esophageal strictures: do they work? Dysphagia 2017;32:575-582.

34. Yano T, Yoda Y, Nomura S, et al. Prospective trial of biodegradable stents for refractory benign esophageal strictures after curative treatment of esophageal cancer. Gastrointest Endosc 2017;86:492499.

35. van Boeckel PG, Vleggaar FP, Siersema PD. A comparison of temporary self-expanding plastic and biodegradable stents for refractory benign esophageal strictures. Clin Gastroenterol Hepatol 2011;9:653-659.

36. Canena JM, Liberato MJ, Rio-Tinto RA, et al. A comparison of the temporary placement of 3 different self-expanding stents for the treatment of refractory benign esophageal strictures: a prospective multicentre study. BMC Gastroenterol 2012;12:70.

37. Dhar A, Close H, Viswanath YK, et al. Biodegradable stent or balloon dilatation for benign oesophageal stricture: pilot randomised controlled trial. World J Gastroenterol 2014;20:1819918206.

38. Walter D, van den Berg MW, Hirdes MM, et al. Dilation or biodegradable stent placement for recurrent benign esophageal strictures: a randomized controlled trial. Endoscopy 2018;50:11461155.

39. van Halsema EE, van Hooft JE. Clinical outcomes of self-expandable stent placement for benign esophageal diseases: A pooled analysis of the literature. World J Gastrointest Endosc 2015;7:135-153.
40. Fuccio L, Hassan C, Frazzoni L, Miglio R, Repici A. Clinical outcomes following stent placement in refractory benign esophageal stricture: a systematic review and meta-analysis. Endoscopy 2016;48:141-148.

41. Karakan T, Utku OG, Dorukoz O, et al. Biodegradable stents for caustic esophageal strictures: a new therapeutic approach. Dis Esophagus 2013;26:319-322.

42. McCain S, McCain S, Quinn B, Gray R, Morton J, Rice P. The role of biodegradable stents in the management of benign and malignant oesophageal strictures: A cohort study. Surgeon 2016;14:322-326.

43. Dumoulin FL, Plassmann D. Tissue hyperplasia following placement of a biodegradable stent for a refractory esophageal stricture: treatment with argon plasma coagulation. Endoscopy 2012;44 Suppl 2 UCTN:E356-E357.

44. Nogales, Clemente A, Caballero-Marcos A, et al. Endoscopically placed stents: a useful alternative for the management of refractory benign cervical esophageal stenosis. Rev Esp Enferm Dig 2017;109:510-515.

45. Orive-Calzada A, Alvarez-Rubio M, Romero-Izquierdo S, et al. Severe epithelial hyperplasia as a complication of a novel biodegradable stent. Endoscopy 2009;41(Suppl 2):E137-E138.

46. Hair CS, Devonshire DA. Severe hyperplastic tissue stenosis of a novel biodegradable esophageal stent and subsequent successful management with high-pressure balloon dilation. Endoscopy 2010;42(Suppl 2):E132-E133.

47. Jung GE, Sauer P, Schaible A. Tracheoesophageal fistula following implantation of a biodegradable stent for a refractory benign esophageal stricture. Endoscopy 2010;42(Suppl 2):E338-E339.

48. Imaz-Iglesia I, García-Pérez S, Nachtnebel A, et al. Biodegradable stents for the treatment of refractory or recurrent benign esophageal stenosis. Expert Rev Med Devices 2016;13:583-599. 